\title{
Yield and quality of potato tubers depending on a complex of chemicals applied under radioactive contamination
}

\author{
Aleksey E. Sekirnikov*, Vladimir V. Sedov, Viktor F. Shapovalov \\ Bryansk State Agrarian University, Bryansk region, Russian Federation \\ *Corresponding author: bgsha@bgsha.com
}

\begin{abstract}
The influence of chemicals on productivity and quality of potato tubers cv. Kurazh cultivated on sod-podzolic sandy soils under radioactive contamination was studied in the south-west of the central Non-Black Soil Zone of the Russian Federation. Organo-mineral system (manure, $40 \mathrm{t} / \mathrm{ha}+\mathrm{N}_{75} \mathrm{P}_{30} \mathrm{~K}_{90}$ ) applied in complex with chemicals and biological agent Gumistim turned to be the most effective fertilizer system providing the maximum potato yields during the experiment. Moreover, complex application of the chemicals increased protein level and decreased starch content in tubers, it also improved amino acid composition; concentration of heavy metals and specific activity of cesium-137 did not exceed sanitary and hygienic standards (SanPiN 2.3.3 1078—01).
\end{abstract}

Key words: potato, yield, marketability, starch, nitrates, heavy metals, amino acids, cesium-137

\section{Introduction}

Potato is one of the leading agricultural crops ensuring the country's food security to a large extent. In terms of acreage, potato is second after cereals and is the most popular in the consumer basket of the population used for the production of a variety of food products. Moreover, it is the most important forage and technical crop [1-3]. The high competitiveness of potatoes and their intended use is largely determined by a number of quality indicators, the most important of which is the bio-chemical composition of tubers [4].

One of the factors affecting the productivity, quality indicators of potato tubers and biochemical composition, is cultivation conditions including soil, climate and optimal mineral fertilizing throughout the growing season [5].

In order to increase potato productivity, it is necessary to use science-based agricultural practices allowing to optimize fertilizer doses, ratio of nutrients, pesticides, humic fertilizers [6], which are natural biochemical active substances stimulating growth, improving plant nutrition, taking part in redox reactions at the cellular level, reducing radionuclide and heavy metal intake, increasing plant resistance and activating anti-stress mechanism in plants [7-9]. 
Vast territories in the south-west of the Non-Black Soil Zone of the Russian Federation are radioactive contaminated, where cesium-137 is the main dose-generating radionuclide. Therefore, the main task of agricultural producers is to introduce scientifically-based agrochemical methods into plant cultivation processes that contribute to reducing transition of ${ }^{137} \mathrm{Cs}$ to marketable products and where potassium fertilizers play a major role [10-12].

The purpose of the research was to study the complex application of fertilizers, chemicals and biological agent Gumistim during cultivation of early potato cultivars grown in sod-podzolic radioactively contaminated sandy soil.

\section{Materials and methods}

The field experiments were carried out on the experimental field of Novozybkov branch of Bryansk State Agrarian University on sod-podzolic, loose-sandy radioactively contaminated soil in 2013-2017. Arable layer of the soil had the following agrochemical parameters: pHkcl $6.7-6.9, \mathrm{Ng}-0.51-0.56 \mathrm{mmol}-\mathrm{EQ} / 100 \mathrm{~g}$ of soil; absorbed alkali — 12.2 - 16.4 mmol-EQ/100 g of soil; mobile phosphorus and exchangeable potassium (according to Kirsanov) - 370 - 390 and 76-86 mg/kg of soil, respectively. Organic matter content was 1.9 to 2.2 (according to Tyurin). The density of ${ }^{137} \mathrm{Cs}$ soil contamination in the experimental plot was $526-666 \mathrm{kBq} / \mathrm{m}^{2}$. Early potato cv. Kurazh was studied in the four-factor experiment, total area of the experimental plot was $90 \mathrm{~m}^{2}$, and the accounting one was $70 \mathrm{~m}^{2}$. The experiment scheme included the following variants: control (without fertilizers); manure $80 \mathrm{t} / \mathrm{ha}$; manure $40 \mathrm{t} / \mathrm{ha}+\mathrm{N}_{75} \mathrm{P}_{30} \mathrm{~K}_{90}$; $\mathrm{N}_{75} \mathrm{P}_{30} \mathrm{~K}_{90} ; \quad \mathrm{N}_{150} \mathrm{P}_{60} \mathrm{~K}_{180} ; \quad \mathrm{N}_{225} \mathrm{P}_{90} \mathrm{~K}_{270} ;$ manure $40 \mathrm{t} / \mathrm{ha}+\mathrm{N}_{75} \mathrm{P}_{30} \mathrm{~K}_{90}+$ pesticides; $\mathrm{N}_{75} \mathrm{P}_{30} \mathrm{~K}_{90}+$ pesticides; $\mathrm{N}_{150} \mathrm{P}_{60} \mathrm{~K}_{180}+$ pesticides; $\mathrm{N}_{225} \mathrm{P}_{90} \mathrm{~K}_{270}+$ pesticides; manure $40 \mathrm{t} / \mathrm{ha}+\mathrm{N}_{75} \mathrm{P}_{30} \mathrm{~K}_{90}+$ pesticides + Gumistim; $\mathrm{N}_{75} \mathrm{P}_{30} \mathrm{~K}_{90}+$ pesticides + Gumistim; $\mathrm{N}_{150} \mathrm{P}_{60} \mathrm{~K}_{180}+$ pesticides + Gumistim; $\mathrm{N}_{225} \mathrm{P}_{90} \mathrm{~K}_{270}+$ pesticides + Gumistim .

Such fertilizers as cattle manure, double granulated superphosphate, potassium chloride were used in the experiments. All the fertilizers were applied in spring during plowing of the fall tillage. Bioagent Gumistim contains biohumus in the dissolved form: humins, vitamins, natural phytohormones, succinic acid, micro-and macronutrients in organic form, and spores of soil microorganisms. The biological agent (6 1/ha) was used in two terms: the first was combined with chemical pesticides in the budding stage, and the second - at the end of flowering. Weeds, pests and diseases on potato plants were controled by the following chemicals: Zencor $50 \%$ a.i. $-0.7 \mathrm{~kg} / \mathrm{ha}$; Titus $0.050 \mathrm{~kg} / \mathrm{ha}$; Ridomil Gold — $2.5 \mathrm{~kg} / \mathrm{ha}$; Sektim Phenomen - $1.25 \mathrm{~kg} / \mathrm{ha}$, Aktara $0.06 \mathrm{~kg} / \mathrm{ha}$. Depending on weather conditions, no less than 3 treatments were carried out during the vegetation period. The farming practice of potato cultivation was generally accepted for the region. Potato planting was carried out in the third decade of April, harvesting - in the first decade of August, tuber harvest was weighted. Field and laboratory-analytical researches were performed according to the generally accepted methods in agrochemical service in the center for collective use of scientific equipment and devices of the Bryansk State Agrarian University [13, 14]. The weather conditions of vegetation periods in the years of field experiments differed in moisture and temperature. 2014 and 2016 were the most favorable for these indicators, less moisture 
was in 2013, 2015 and 2017, characterized by low soil productive moisture in the arable soil horizon, insufficient rainfall and uneven precipitation. These circumstances resulted in fluctuations in potato tuber yields over the research years.

\section{Rezults and dicussion}

Potato yield was the lowest in the control variant and averaged $9.3 \mathrm{t} / \mathrm{ha}$ for 5 research years (Table 1).

Table 1

Yield and quality of potato tubers depending on the chemicals applied (average for 2013-AL2017)

\begin{tabular}{|l|c|c|c|c|c|}
\hline \multicolumn{1}{|c|}{ Variant } & $\begin{array}{c}\text { Yield, } \\
\text { t/ha }\end{array}$ & $\begin{array}{c}\text { Increase } \\
\text { compared } \\
\text { to control, t/ha }\end{array}$ & $\begin{array}{c}\text { Starch } \\
\text { content, \% }\end{array}$ & $\begin{array}{c}\text { Protein } \\
\text { content, \% }\end{array}$ & $\begin{array}{c}\text { Protein } \\
\text { yield, } \mathrm{t} / \text { ha }\end{array}$ \\
\hline Control without fertilizers & 9.3 & - & 13.0 & 2.06 & 0.202 \\
\hline Manure 80 t/ha & 20.5 & 11.2 & 12.6 & 2.16 & 0.469 \\
\hline Manure 40 t/ha $+\mathrm{N}_{75} \mathrm{P}_{30} \mathrm{~K}_{90}$ & 25.9 & 16.6 & 12.4 & 2.26 & 0.640 \\
\hline $\mathrm{N}_{75} \mathrm{P}_{30} \mathrm{~K}_{90}$ & 22.0 & 12.7 & 12.3 & 2.15 & 0.520 \\
\hline $\mathrm{N}_{150} \mathrm{P}_{60} \mathrm{~K}_{180}$ & 23.8 & 14.5 & 11.8 & 2.24 & 0.589 \\
\hline $\mathrm{N}_{225} \mathrm{P}_{90} \mathrm{~K}_{270}$ & 23.0 & 13.7 & 11.6 & 2.34 & 0.583 \\
\hline Manure 40 t/ha + $\mathrm{N}_{75} \mathrm{P}_{30} \mathrm{~K}_{90}+$ pesticides & 30.7 & 21.4 & 12.2 & 2.41 & 0.786 \\
\hline $\mathrm{N}_{75} \mathrm{P}_{30} \mathrm{~K}_{90}+$ pesticides & 23.5 & 14.2 & 12.3 & 2.16 & 0.553 \\
\hline $\mathrm{N}_{150} \mathrm{P}_{60} \mathrm{~K}_{180}+$ pesticides & 27.8 & 18.5 & 12.0 & 2.25 & 0.648 \\
\hline $\mathrm{N}_{225} \mathrm{P}_{90} \mathrm{~K}_{270}+$ pesticides & 26.2 & 16.9 & 11.7 & 2.37 & 0.633 \\
\hline $\begin{array}{l}\text { Manure 40 t/ha }+\mathrm{N}_{75} \mathrm{P}_{30} \mathrm{~K}_{90}+\text { pesti- } \\
\text { cides + Gumistim }\end{array}$ & 35.1 & 25.8 & 12.4 & 2.51 & 0.876 \\
\hline $\mathrm{N}_{75} \mathrm{P}_{30} \mathrm{~K}_{90}+$ pesticides + Gumistim & 25.2 & 15.9 & 12.4 & 2.28 & 0.620 \\
\hline $\mathrm{N}_{150} \mathrm{P}_{60} \mathrm{~K}_{180}+$ pesticides + Gumistim & 31.1 & 21.8 & 12.5 & 2.39 & 0.786 \\
\hline $\mathrm{N}_{225} \mathrm{P}_{90} \mathrm{~K}_{270}+$ pesticides + Gumistim & 27.2 & 17.9 & 12.5 & 2.46 & 0.726 \\
\hline $\mathrm{HCPO5}, \mathrm{t} /$ ha & 2.7 & - & 0.64 & 0.16 & - \\
\hline
\end{tabular}

Organic fertilizer (litter manure $80 \mathrm{t} / \mathrm{ha}$ ) increased yields of potato tubers by $11.9 \mathrm{t} / \mathrm{ha}$ compared to the control, amounting to $21.7 \mathrm{t} / \mathrm{ha}$. The use of mineral fertilizers in the dose of $\mathrm{N}_{150} \mathrm{P}_{60} \mathrm{~K}_{180}$ (according to the number of nutrients, a manure dose of $80 \mathrm{t} / \mathrm{ha}$ ) resulted in $23.8 \mathrm{t} /$ ha potato yields, which was $14.5 \mathrm{t} /$ ha higher compared with the control, and $3.3 \mathrm{t} /$ ha higher compared to variant with $80 \mathrm{t} / \mathrm{ha}$ of manure. The results indicate a higher availability of nutrients contained in mineral fertilizers and a higher coefficient of their use in the first year after application of relatively organic fertilizer. Applying organic fertilizer (manure $40 \mathrm{t} / \mathrm{ha}+\mathrm{N}_{75} \mathrm{P}_{30} \mathrm{~K}_{90}$ ) increased potato yield by $16.6 \mathrm{t} /$ ha compared to the control, and by $5.4 \mathrm{t} / \mathrm{ha}$ compared to organic system (manure $80 \mathrm{t} / \mathrm{ha}$ ). The use of higher doses of NPK $\left(\mathrm{N}_{225} \mathrm{P}_{90} \mathrm{~K}_{270}\right)$, especially under deficit soil moisture and high air temperatures, did not contributed to the adequate increase in potato tubers, the yields of tubers was at the level of the average NPK dose $\left(\mathrm{N}_{150} \mathrm{P}_{60} \mathrm{~K}_{180}\right)$. Cultivating potato plants with pesticide application contributed to a further potato yield increase which averaged 1.5 - 4.8 tha. The higher yields of potato tubers were observed while appliing fertilizers, chemical plant protection means and biological agent Gumistim in complex. On average, over the research years, the increase in potato yield reached the level of $15.9-25.8 \mathrm{t} / \mathrm{ha}$ under complex use of chemicals in comparison with the control. The highest potato yield - 35.1 t/ha - in was obtained in the variant with organic-mineral system of fertilizing in combination with pesticides and biological agent Gumistim (manure $40 \mathrm{t} / \mathrm{ha}+$ $+\mathrm{N}_{75} \mathrm{P}_{30} \mathrm{~K}_{90}+$ pesticides + Gumistim). 
On average over the research years, starch content decreased by $0.5-1.9 \%$ under the influence of the studied means of chemicalization. The applied systems of fertilizer both at separate, and at complex application promoted an increase in the protein content of potato tubers from 2.06 up to $2.51 \%$. The protein content of potato tubers increased on average by $0.13-0.25 \%$ under complex use of chemicals. The maximum protein yield $(0.876 \mathrm{t} / \mathrm{ha})$ resulted from organic mineral fertilizing combined with plant protection means and Gumistim.

Quantitative changes in the amino acid composition of potato tubers depended on the studied fertilizer systems (Table 2) on average over 5 years. In quantitative terms aspartic acid and leucine were allocated.

The tubers of potatoes contain the least of histidinum and methionine referring to irreplaceable amino acids. The largest number of essential amino acids (\% of the total amount of all amino acids), 38.0 and $39.0 \%$, was obtained in the organic mineral fertilizer system (manure $\left.40 \mathrm{t} / \mathrm{ha}+\mathrm{N}_{75} \mathrm{P}_{30} \mathrm{~K}_{90}\right)$, mineral $\left(\mathrm{N}_{150} \mathrm{P}_{60} \mathrm{~K}_{180}\right)$ in complex with plant protection means and biological agent Gumistim.

Table 2

The effect of fertilizers, chemicals and Gumistim bioagent on amino acid composition of potato tubers, tons per $1 \mathrm{~kg}$ of dry mass (average for 2013-2017)

\begin{tabular}{|c|c|c|c|c|c|}
\hline \multirow{3}{*}{ Amino Acids } & \multicolumn{5}{|c|}{ Variants } \\
\hline & \multirow[b]{2}{*}{ Control } & \multicolumn{3}{|c|}{ Manure $40 \mathrm{t} / \mathrm{ha}+$} & \multirow[b]{2}{*}{$\begin{aligned} & \mathrm{N}_{75} \mathrm{P}_{30} \mathrm{~K}_{90} \\
+ & \text { pesticides } \\
+ & \text { Gumistim }\end{aligned}$} \\
\hline & & $+\mathrm{N}_{75} \mathrm{P}_{30} \mathrm{~K}_{90}$ & $\begin{array}{l}+\mathrm{N}_{75} \mathrm{P}_{30} \mathrm{~K}_{90} \\
+ \text { pesticides }\end{array}$ & $\begin{array}{l}+\mathrm{N}_{75} \mathrm{P}_{30} \mathrm{~K}_{90} \\
+ \text { pesticides } \\
+ \text { Gumistim }\end{array}$ & \\
\hline Alanine & 5.82 & 5.76 & 5.48 & 6.88 & 5.86 \\
\hline Arginine & 4.46 & 4.53 & 4.62 & 4.66 & 4.68 \\
\hline Asparagine & 18.42 & 18.56 & 18.86 & 18.88 & 18.76 \\
\hline Valine $^{\star}$ & 5.82 & 5.58 & 5.64 & 5.91 & 5.86 \\
\hline Histidine $^{\star}$ & 1.29 & 1.42 & 1.46 & 1.53 & 1.52 \\
\hline Glycine & 3.71 & 3.84 & 3.88 & 3.93 & 3.92 \\
\hline Glutamine & 5.09 & 5.13 & 5.18 & 5.22 & 5.26 \\
\hline Isoleucine $^{\star}$ & 3.32 & 3.48 & 3.53 & 4.12 & 3.86 \\
\hline Leucine * & 6.92 & 7.29 & 7.38 & 7.42 & 8.54 \\
\hline Lysine* & 4.58 & 4.66 & 4.85 & 5.13 & 5.26 \\
\hline Methionine $^{\star}$ & 1.66 & 1.68 & 1.72 & 1.74 & 1.76 \\
\hline Promin & 6.32 & 6.46 & 6.56 & 7.54 & 6.73 \\
\hline Serine & 4.36 & 4.41 & 4.46 & 4.63 & 4.52 \\
\hline Tyrosine & 4.06 & 4.43 & 4.48 & 5.18 & 4.52 \\
\hline Threonine & 3.66 & 3.84 & 3.88 & 3.92 & 3.90 \\
\hline Tryptophan* & 4.36 & 4.43 & 4.52 & 5.21 & 4.58 \\
\hline Phenylalanine* & 3.88 & 4.26 & 4.35 & 5.13 & 5.09 \\
\hline Amount & 87.73 & 89.73 & 90.85 & 95.43 & 94.62 \\
\hline $\begin{array}{l}\text { Essential amino } \\
\text { acids, \% of total } \\
\text { amino acids }\end{array}$ & 37.0 & 37.0 & 37.0 & 38.0 & 39.0 \\
\hline
\end{tabular}

Note: *essential amino acids.

It was established that concentration of heavy metals under the influence of the applied means of chemicalization changed (Table 2). Thus, concentration of copper in potato tubers varied on average from 1.35 to $1.46 \mathrm{mg} / \mathrm{kg}$ dry mass in the variants of the experiment. 
The content of heavy metals and cesium-137 in potato tubers depending

Table 3 on the chemicals used (2013-2015)

\begin{tabular}{|c|c|c|c|c|c|c|c|}
\hline \multirow{2}{*}{ Variant } & \multicolumn{5}{|c|}{ Content, $\mathrm{mg} / \mathrm{kg}$} & \multirow{2}{*}{$\begin{array}{c}\text { Specific } \\
\text { Activity }{ }^{137} \mathrm{Cs} \text {, } \\
\text { BK/kg }\end{array}$} & \multirow{2}{*}{$\begin{array}{l}\text { Reduction } \\
\text { ratio, times }\end{array}$} \\
\hline & $\mathrm{Cu}$ & $\mathrm{Pb}$ & $\mathrm{Zn}$ & $\mathrm{Mn}$ & $\mathrm{Cd}$ & & \\
\hline Control without fertilizers & 1.35 & 0.11 & 3.86 & 11.21 & 0.01 & 80 & - \\
\hline Manure $80 \mathrm{t} / \mathrm{ha}$ & 1.37 & 0.16 & 2.53 & 10.87 & 0.015 & 30 & 2.67 \\
\hline Manure $40 \mathrm{t} / \mathrm{ha}+\mathrm{N}_{75} \mathrm{P}_{30} \mathrm{~K}_{90}$ & 1.22 & 0.12 & 0.36 & 12.04 & 0.015 & 26 & 3.08 \\
\hline $\mathrm{N}_{75} \mathrm{P}_{30} \mathrm{~K}_{90}$ & 1.32 & 0.08 & 3.18 & 9.16 & 0.015 & 21 & 3.81 \\
\hline $\mathrm{N}_{150} \mathrm{P}_{60} \mathrm{~K}_{180}$ & 1.43 & 0.06 & 3.52 & 11.18 & 0.02 & 20 & 4.00 \\
\hline $\mathrm{N}_{225} \mathrm{P}_{90} \mathrm{~K}_{270}$ & 1.46 & 0.22 & 3.75 & 11.56 & 0.025 & 17 & 4.71 \\
\hline $\begin{array}{l}\text { Manure } 40 \mathrm{t} / \mathrm{ha}+\mathrm{N}_{75} \mathrm{P}_{30} \mathrm{~K}_{90}+ \\
\text { + pesticides }\end{array}$ & 1.12 & 0.11 & 2.30 & 9.97 & 0.015 & 19 & 4.21 \\
\hline $\mathrm{N}_{75} \mathrm{P}_{30} \mathrm{~K}_{90}+$ pesticides & 0.86 & 0.06 & 2.12 & 10.26 & 0.015 & 23 & 3.48 \\
\hline $\mathrm{N}_{150} \mathrm{P}_{60} \mathrm{~K}_{180}+$ pesticides & 0.68 & 0.06 & 2.42 & 11.18 & 0.018 & 18 & 3.44 \\
\hline $\mathrm{N}_{225} \mathrm{P}_{90} \mathrm{~K}_{270}+$ pesticides & 1.32 & 0.13 & 2.48 & 12.45 & 0.025 & 16 & 5.00 \\
\hline $\begin{array}{l}\text { Manure } 40 \mathrm{t} / \mathrm{ha}+\mathrm{N}_{75} \mathrm{P}_{30} \mathrm{~K}_{90}+ \\
\text { + pesticides + Gumistim }\end{array}$ & 1.06 & 0.10 & 2.09 & 11.16 & 0.01 & 17 & 4.71 \\
\hline $\mathrm{N}_{75} \mathrm{P}_{30} \mathrm{~K}_{90}+$ pesticides + Gumistim & 0.74 & 0.06 & 2.18 & 10.17 & 0.012 & 17 & 4.41 \\
\hline $\mathrm{N}_{150} \mathrm{P}_{60} \mathrm{~K}_{180}+$ pesticides + Gumistim & 1.18 & 0.05 & 2.22 & 10.13 & 0.015 & 14 & 5.71 \\
\hline $\mathrm{N}_{225} \mathrm{P}_{90} \mathrm{~K}_{270}+$ pesticides + Gumistim & 1.26 & 0.10 & 2.34 & 9.60 & 0.02 & 10 & 8.0 \\
\hline $\mathrm{MAC}, \mathrm{Mg} / \mathrm{kg}$ & 5.0 & 0.5 & 10.0 & - & 0.03 & & \\
\hline
\end{tabular}

The introduction of consistently increasing doses of mineral fertilizers resulted in increase in concentration of copper in potato tubers compared to the control, but its concentration in tubers did not exceed the marginal acceptable concentration (MAC).

The concentration of lead varied in the range of $0.05-0.22 \mathrm{mg} / \mathrm{kg}$ in variants on average over the research years. Complex application of chemicals (var. 7-14) contributed to decrease in concentration of lead in potato tubers in comparison with the control.

Content of manganese in potato tubers varied from 9.16 to $12.45 \mathrm{mg} / \mathrm{kg}$ according to the variants of the experiment, with its concentration in tubers of $11.21 \mathrm{mg} / \mathrm{kg}$.

The potassium content in potato tubers did not exceed the threshold value $(0.03 \mathrm{mg} / \mathrm{kg})$ on average over the research years, and it was within the marginal acceptable concentration (MAC).

During five-year research specific activity of cesium-137 in the control variant was $80 \mathrm{~Bq} / \mathrm{kg}$ (standard $120 \mathrm{~Bq} / \mathrm{kg}$ ). The applied chemicals contributed to the reduction of specific activity of ${ }^{137} \mathrm{Cs}$ in potato tubers. The application of organic fertilizer system (manure $80 \mathrm{t} / \mathrm{ha}$ ) resulted in 2.67 -fold reducing the specific activity of ${ }^{137} \mathrm{Cs}$ in potato tubers in comparison with the control. Organic-mineral system of fertilizer caused 3-fold decrease in specific activity of cesium-137 in potato tubers compared to the control. The use of the mineral fertilizer system with consistently increasing doses of NPK reduced the specific activity of ${ }^{137} \mathrm{Cs}$ in potato tubers by $3.81-4.71$ times. The use of plant protection chemicals has also contributed to the reduction in the specific activity of ${ }^{137} \mathrm{Cs}$ in potato tubers through biological dilution while increasing the yields of potato tubers in these variants.

Complex application of chemicals contributed to the reduction of specific activity of cesium-137 in potato tubers compared to the control variant. The greatest decrease in the specific activity of ${ }^{137} \mathrm{Cs}\left(8.0\right.$ times) was obtained in the variant $\mathrm{N}_{225} \mathrm{R}_{90} \mathrm{~K}_{270}$ in combination with pesticides and bio-agent Gumistim (var. 14). 


\section{Conclusions}

Thus, while cultivating potatoes in sod-podzolic sandy radioactively contaminated soil the maximum yields of potato tubers of $31.1 \mathrm{t} /$ ha was achieved by using the organicmineral system of fertilizers (manure 40 t/ha $+\mathrm{N}_{75} \mathrm{P}_{30} \mathrm{~K}_{90}$ ) in complex with plant protection agents and Gumistim. The applied fertilizer systems, both in separate application and in combination with the pesticides and Gumistim reduced the starch content in tubers by $1.5-1.9 \%$, and increased the protein content in tubers on average by 0.13 $0.25 \%$. The maximum protein yield of $0.876 \mathrm{t} / \mathrm{ha}$ was ensured the variant with organic mineral system (manure $40 \mathrm{t} / \mathrm{ha}+\mathrm{N}_{75} \mathrm{P}_{30} \mathrm{~K}_{90}$ ) in combination with pesticides and bioagent Gumistim. The greatest level of essential amino acids in potato tubers was provided by the organic-mineral (manure $\left.40 \mathrm{t} / \mathrm{ha}+\mathrm{N}_{75} \mathrm{P}_{30} \mathrm{~K}_{90}\right)$ and mineral $\left(\mathrm{N}_{150} \mathrm{P}_{60} \mathrm{~K}_{180}\right)$ systems in combination with plant protection means and Gumistim. The concentration of heavy metals in potato tubers in all studied fertilizer systems did not exceed MAC. Specific activity of ${ }^{137} \mathrm{Cs}$ in potato tubers was reduced from $2.67-8.0$ times both in separate and complex application under the influence of the studied fertilizer systems.

\section{REFERENCES}

1. Vorobiev VA. Evaluation of potato fertilization systems under field crop rotations. Agrarian science. 2015; (3):14-16. (In Russ).

2. Korshunov AV, Simakov EA, Lysenko YN, Anisimov BV, Mityushkin AV, Gaitov MY. Actual problems and priority directions of innovative development of potato breeding. Achievements of Science and Technology of AIC. 2018; 32(3):12-20. (In Russ). Available from: doi: 10.24411/0235-2451-2018-10303.

3. Alsmik PI. Potato Selection in Belarus. Minsk: Urozhai Publ.; 1979. (In Russ).

4. Vlasenko NE. Potato fertilizing. Moscow: Agropromizdat Publ., 1987. (In Russ).

5. Mikhailova LA, Aleshin MA, Aleshina DV. Efficiency of potash fertilizers in the cultivation of potato variety Nevsky on sod-podzolic heavy loamy soil. Glavnyi agronom [Chief Agronomist]. 2012; (3):23-25. (In Russ).

6. Sychev VG, Shapovalov VF, Belous NM, Shlyk DP. Fertilization and protection of potatoes in conditions of radioactive contamination. Plodorodie. 2004; (5):37-38. (In Russ).

7. Makarov OA, Stepanov AA, Cherkashina NF, Chistova OA, Panina NN. Experience of the assessment of influence of humic preparations on productivity and quality of potatoes. Agrochemical Herald. 2016; (1):22-26. (in Russ)

8. Matevosyan LG, Kudashov AA. Action of growth regulators, stability inductors and herbicides in potato cultivation. In: Plant Protection and Growth Regulation of Vegetable Crops and Potatoes. Saint Petersburg: SPbSAU Publ.; 2004. p. 70-82. (In Russ).

9. Butov AV, Adoniev SO. Plant growth regulators on potato. Potato and Vegetables. 2015; (5):29-30. (In Russ).

10. Manukyan AI, Romanova MS, Khaksar EV, Murzin AI, Martynov MS. Effects of humic fertilizer Gumostim from peat and different types of containers on growth of improved potato plants. Achievements of Science and Technology of AIC. 2016; 30(10):69-70. (In Russ).

11. Shapovalov VF, Belous NM, Malyavko GP, Kharkevich LP. The effect of chemicals on productivity and quality of oats in the conditions of radioactive pollution. Grain Economy of Russia. 2016; (2):68-72. (In Russ).

12. Malyavko GP, Belous NM, Shapovalov VF. Scientific Substantiation of cultivation technologies of winter rye in the South-West of Russia. Bryansk: Bryansk State Agricultural Academy Bubl.; 2010. (In Russ). 
13. Belous NM, Anishina YA, Shapovalov VF, Smolski EV. Potash fertilizers as a factor of influence on the content of cesium-137 in green mass of perennial grasses. Vestnik of the Bryansk State Agricultural Academy. 2012; (1):54-61. (In Russ).

14. Dospekhov BA. Metodika polevogo opyta [Methods of field experiments]. Moscow: Agropromizdat Publ.; 1985. (In Russ).

15. Methodical instructions for determination of natural radionuclides in soils and plants. Moscow: TsINAO Publ.; 1985. (In Russ).

\title{
Article history:
}

Received: 27 March 2019

Accepted: 26 April 2019

\begin{abstract}
About authors:
Sekirnikov Aleksey Evgenievich - Postgraduate Student of the Department of Agrochemistry, soil science and ecology, Bryansk State Agrarian University; 2a, Sovetskaya st., Kokino village, Vygonichi district, Bryansk region, 243365, Russian Federation; e-mail: bgsha@bgsha.com

Sedov Vladimir Vitalievich - Postgraduate Student of the Department of Agrochemistry, soil science and ecology, Bryansk State Agrarian University; 2a, Sovetskaya st., Kokino village, Vygonichi district, Bryansk region, 243365, Russian Federation; e-mail: bgsha@bgsha.com

Shapovalov Viktor Fedorovich - Doctor of Science in Agriculture, Professor of the Department of Agrochemistry, soil science and ecology, Bryansk State Agrarian University; 2a, Sovetskaya st., Kokino village, Vygonichi district, Bryansk region, 243365, Russian Federation; e-mail:bgsha@bgsha.com
\end{abstract}

For citation:

Sekirnikov AE, Sedov VV, Shapovalov VF. Yield and quality of potato tubers depending on a complex of chemicals applied under radioactive contamination. RUDN Journal of Agronomy and Animal Industries. 2019; 14(2):133—141. doi: 10.22363/2312-797X-2019-14-2-133-141.

Научная статья

\section{Продуктивность и качество клубней картофеля в зависимости от комплекса применяемых средств химизации} в условиях радиоактивного загрязнения агроценозов

\author{
А.Е. Секирников*, В.В. Седов, В.Ф. Шаповалов \\ Брянский государственный аграрный университет, \\ Брянская область, Российская Федерация \\ *bgsha@bgsha.com
}

\begin{abstract}
Аннотация. В условиях радиоактивного загрязнения сельскохозяйственных угодий юго-запада Центрального Нечерноземья Российской Федерации изучали влияние комплексного применения средств химизации на продуктивность и качество клубней картофеля сорта Кураж, возделываемого в плодосменном севообороте на дерново-подзолистой песчаной почве. Показано, что в условиях
\end{abstract}


проводимого эксперимента оптимальной системой удобрения, обеспечивающей максимальную урожайность клубней, оказалась органоминеральная система (навоз 40 т/га $+\mathrm{N}_{75} \mathrm{P}_{30} \mathrm{~K}_{90}$ ), применяемая в комплексе с химическими средствами защиты растений от вредных организмов и биопрепаратом Гумистим. Отмечено, что под влиянием комплексного применения изучаемых средств химизации повышалась белковость и снижалась крахмалистость, улучшался аминокислотный состав, концентрация тяжелых металлов и удельная активность цезия-137 не превышала санитарно-гигиенических нормативов (СанПиН 2.3.3 1078-01).

Ключевые слова: картофель, урожайность, товарность, крахмал, нитраты, тяжелые металлы, аминокислоты, цезий-137

\section{БИБЛИОГРАФИЧЕСКИЙ СПИСОК}

1. Воробьев В.А. Оценка систем удобрения картофеля в полевом севообороте // Аграрная наука. 2015. № 3. С. 14-16.

2. Коршунов А.В., Симаков Е.А., Лысенко Ю.Н., Анисимов Б.В., Митюшкин А.В., Гаитов М.Ю. Актуальные проблемы и приоритетные направления развития картофелеводства // Достижения науки и техники АПК. 2018. Т. 32. № 3. С. 12-20. doi: 10.24411/02352451-2018-10303.

3. Альсмик П.И. Селекция картофеля в Белоруссии. Минск: Урожай, 1979. 128 с.

4. Власенко Н.Е. Удобрение картофеля. М.: Агпромиздат, 1987. 219 с.

5. Михайлова Л.А., Алешин М.А., Алешина Д.В. Эффективность калийных удобрений при возделывании картофеля сорта Невский на дерново-подзолистой тяжелосуглинистой почве // Главный агроном. 2012. № 3. С. 23-25.

6. Сычев В.Г., Шаповалов В.Ф., Белоус Н.М., Шлык Д.П. Удобрение и защита картофеля в условиях радиоактивного загрязнения // Плодородие. 2004. № 5. С. 37-38.

7. Макаров О.А., Степанов А.А., Черкашина Н.Ф., Чистова О.А., Панина Н.Н. Опыт оценки влияния гуминовых препаратов на урожайность и качество картофеля // Агрохимический вестник. 2016. № 1. С. 22-26.

8. Матевосян Г.Л., Кудашов А.А. Действие регуляторов роста, индукторов устойчивости и гербицидов при выращивании картофеля // Защита и регуляция роста овощных культур и картофеля: сб. научн. тр. СПб.: СПГАУ, 2004. С. 70-82.

9. Бутов А.В., Адоньев С.О. Регуляторы роста на картофеле // Картофель и овощи. 2015. № 5. С. $29-30$.

10. Манукян А.И., Романова М.С., Хаксар Е.В., Мурзин А.И., Мартынов М.С. Изучение влияния гуминового удобрения из торфа Гумостим и различных вариантов сосудов на рост растений оздоровленного картофеля // Достижения науки и техники АПК. 2016. Т. 30. № 10. С. $69-70$.

11. Шаповалов В.Ф., Белоус Н.М., Малявко Г.П., Харкевич Л.П. Действие средств химизации на урожайность и качество зерна овса в условиях радиоактивного загрязнения // Зерновое хозяйство России. 2016. № 2. С. 68-72.

12. Малявко Г.П., Белоус Н.М., Шаповалов В.Ф. Научное обоснование технологий возделывания озимой ржи на юго-западе России. Брянск: Изд-во Брянской ГСХА, 2010. 247 с.

13. Белоус Н.М., Анишина Ю.А., Шаповалов В.Ф., Смольский Е.В. Калийные удобрения как фактор влияния на содержание в зеленой массе многолетних трав цезия-137 // Вестник Брянской государственной сельскохозяйственной академии. 2012. № 1. С. 54-61.

14. Доспехов Б.А. Методика полевого опыта. М.: Агропромиздат, 1985. 357 с.

15. Методические указания по определению естественных радионуклидов в почвах и растениях. М.: ЦИНАО, 1985. 22 с.

\section{История статьи:}

Поступила в редакцию: 27 марта 2019 г.

Принята к публикации: 26 апреля 2019 г. 


\section{Об авторах:}

Секирников Алексей Евгеньевич - аспирант кафедры агрохимии, почвоведения и экологии, Брянский государственный аграрный университет, Российская Федерация, 243365, Брянская обл., Выгоничский р-н, с. Кокино, ул. Советская, 2a; e-mail: bgsha@bgsha.com

Седов Владимир Витальевич - аспирант кафедры агрохимии, почвоведения и экологии, Брянский государственный аграрный университет, Российская Федерация, 243365, Брянская обл., Выгоничский р-н, с. Кокино, ул. Советская, 2a; e-mail: bgsha@bgsha.com

Шаповалов Виктор Федорович - доктор сельскохозяйственных наук, профессор кафедры агрохимии, почвоведения и экологии, Брянский государственный аграрный университет, Российская Федерация, 243365, Брянская обл., Выгоничский р-н, с. Кокино, ул. Советская, 2a; e-mail:bgsha@bgsha.com

\section{Для цитирования:}

Sekirnikov A.E., Sedov V.V, Shapovalov V.F. Yield and quality of potato tubers depending on a complex of chemicals applied under radioactive contamination // Вестник Российского университета дружбы народов. Серия: Агрономия и животноводство. 2019. Т. 14. № 2. С. 133-141. doi: 10.22363/2312-797X-2019-14-2-133-141. 